\title{
Mushroom Cosmetics: The Present and Future
}

\author{
Yuanzheng $\mathrm{Wu}^{1,2}$, Moon-Hee Choi ${ }^{1}$, Jishun $\mathrm{Li}^{2}{ }^{2}$, Hetong Yang ${ }^{2}$ and Hyun-Jae Shin ${ }^{1, *}$ \\ 1 Department of Chemical Engineering, Graduate School of Chosun University, Gwangju 501-759, Korea; \\ wuyzh@sdas.org (Y.W.); aamoony1222@naver.com (M.-H.C.) \\ 2 Biology Institute of Shandong Academy of Sciences, Jinan 250014, China; yewu2@sdas.org (J.L.); \\ yanght@sdas.org (H.Y.) \\ * Correspondence: shinhj@chosun.ac.kr; Tel.: +82-62-230-7518
}

Academic Editor: Enzo Berardesca

Received: 12 May 2016; Accepted: 4 July 2016; Published: 8 July 2016

\begin{abstract}
Mushrooms have been valued as a traditional source of natural bioactive compounds for centuries and have recently been exploited for potential components in the cosmetics industry. Numerous mushrooms and their ingredients have been known to be beneficial to the skin and hair. The representative ingredients are as follows: phenolics, polyphenolics, terpenoids, selenium, polysaccharides, vitamins, and volatile organic compounds. These compounds show excellent antioxidant, anti-aging, anti-wrinkle, skin whitening, and moisturizing effects, which make them ideal candidates for cosmetics products. This review provides some perspectives of mushrooms (and/or extracts) and their ingredients presently used, or patented to be used, in both cosmeceuticals for topical administration and nutricosmetics for oral administration. With the small percentage of mushrooms presently identified and utilized, more mushroom species will be discovered, verified, and cultivated in the future, boosting the development of relevant industry. Combining with progress in genomics, proteomics, metabolomics, and systems pharmacology, mushrooms can find their way into cosmetics with multiple approaches.
\end{abstract}

Keywords: mushrooms; cosmetics; cosmeceuticals; nutricosmetics; anti-aging; antioxidant; skin whitening; moisturizing; skin and hair

\section{Introduction}

Mushrooms are fungi belonging to the higher phyla Ascomycota and Basidiomycota that have a stem (stipe), a cap (pileus), and gills (lamellae, sing. lamella) on the underside of the cap [1,2]. In fact, the name mushroom refers to a fruiting body, formed by several hyphae that grow upwards and produce spores (basidiospores). Mushrooms have long been appreciated for their flavor, texture, and nutrition as culinary mushrooms, but also for pharmaceutical and tonic attributes as medicinal mushrooms [3]. The number of mushroom species on Earth is currently estimated at 150,000, yet perhaps only 10\% (approximately 15,000 named species) have been identified [4,5]. Mushrooms are rich in protein, vitamins, minerals, and excellent sources of $\beta$-glucan, selenium, thiamine, riboflavin, niacin, panthothenic acid, and folic acid, etc. [6,7]. It has reported that mushrooms provide beneficial effects as invigorating vital energy, maintaining one's optimal weight, favoring longevity, and avoiding unnecessary aging [8,9]. Recently mushrooms have drawn worldwide attention as the most interesting natural sources with diverse and unique bioactivities, including immunomodulatory, antioxidant, anti-inflammatory, antidiabetic, antibacterial, antifungal, antiviral, antitumor, hepatoprotective, reducing glucose and lipidic levels [10,11]. They make up a vast, and yet largely untapped, source of powerfully new pharmaceutical products.

Cosmetics are products that are used to cleanse and beautify the skin, also referred to as personal care products [12]. Today, there is a growing consumer demand for cosmetics containing natural and/or organic ingredients as the consumer demand for products that are perceived as healthier, organic, 
and ecological [13]. Thus, various substances extracted from macro fungi, particularly mushrooms, are now paving their way into cosmetics, such as ceramides, lentinan, schizophyllan, omega 3, 6, and 9 fatty acids, carotenoids, resveratrol, and others [14,15]. Many mushroom ingredients possess potent antioxidant, as well as anti-inflammatory, properties, which are frequently used in an effort to address cosmetic concerns, such as fine lines, wrinkles, uneven tone, and texture. As shown in Figure 1, the nutritive, anti-inflammatory, regenerative, and antioxidant properties of mushrooms make for their prospective usage in cosmeceuticals and nutricosmetics [16].

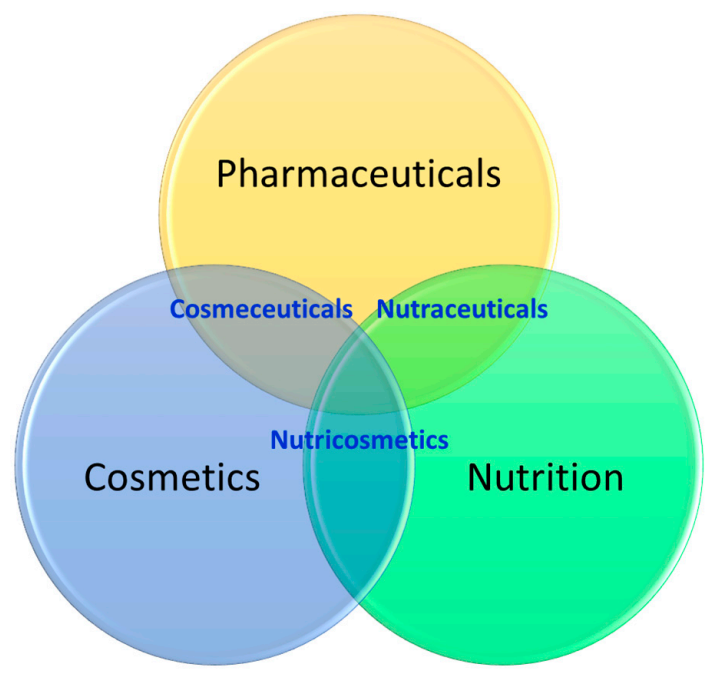

Figure 1. Major applications of mushroom in pharmaceutical, cosmetics, and nutrition, and their interactions.

In this review some major ingredients of mushrooms and important effects, such as moisturizing and anti-aging (including the whitening and antioxidant activity), will be comprehensively discussed, and it will be proposed that mushrooms and their extracts (and/or ingredients) are one of the most ideal choices in the application of cosmetic products.

\section{Mushrooms: Nutritional and Medicinal Facts}

For centuries, people across the world have been using wild mushrooms for food, medicine, and cosmetics, as well as for other economic and cultural purposes. Nowdays several types of mushrooms are incorporated in topical creams, lotions, ointments, serums, and facial preparations as cosmetic ingredients. These mushrooms include Shiitake (Lentinula edodes), Maitake (Grifola frondosa), Reishi or Lingzhi (Ganoderma lucidum), Fu Ling (Wolfiporia extensa), Yartsa Gunbu (Cordyceps sinensis), cauliflower mushroom (Sparassis latifolia, formerly Sparassis crispa), and jelly fungi (Tremella spp.), which are traditionally used in Eastern Asian countries, such as China, Japan, and Korea [17-19]. Portobello mushroom (Agaricus bisporus), oyster mushroom (Pleurotus ostreatus), elm oyster mushroom (Hypsizygus ulmarius), and tinder fungus (Fomes fomentarius), are more recognized in Western countries [20-22]. Other popular mushrooms include Agaricus subrufescens, Coprinus comatus, Hericium erinaceus, Mycoleptodonoides aitchisonii, Phellinus linteus, Schizophyllum commune, and Volvareilla volvacea [23-26]. There are numerous potential mycochemicals from mushrooms that could be used in cosmeceuticals or nutricosmetics. Some of the mycochemicals derived from various mushrooms and their corresponding activities are listed in Table 1 [27-31]. There are still plenty other mushroom species which might have significant potential for use in the cosmetic industry that are currently undetermined, undescribed, or not yet cultivatable [14,32].

The topical extraction process of mushroom ingredients can also be used for cosmetics preparation. Both fruiting bodies and mycelia of wild and cultivatable mushrooms represent ample sources of active components. The compounds so obtained from mushrooms are relatively complex mixtures of 
metabolites, in liquid or semisolid states, or in dry powder form, and are intended for external or oral use for cosmeceuticals or nutricosmetics. The mushroom extracts are often cited as potent antioxidants and natural moisturizers because they can offer a slightly different set of absorbable nutrients than other typical ingredients like vitamin C, vitamin E, and all of the other usual suspects [33]. They contain antioxidants, as well as compounds that have anti-inflammatory properties, which help treat many skin problems caused by inflammation and excessive free radical activity.

Table 1. Mycochemical analysis and activities from various mushrooms.

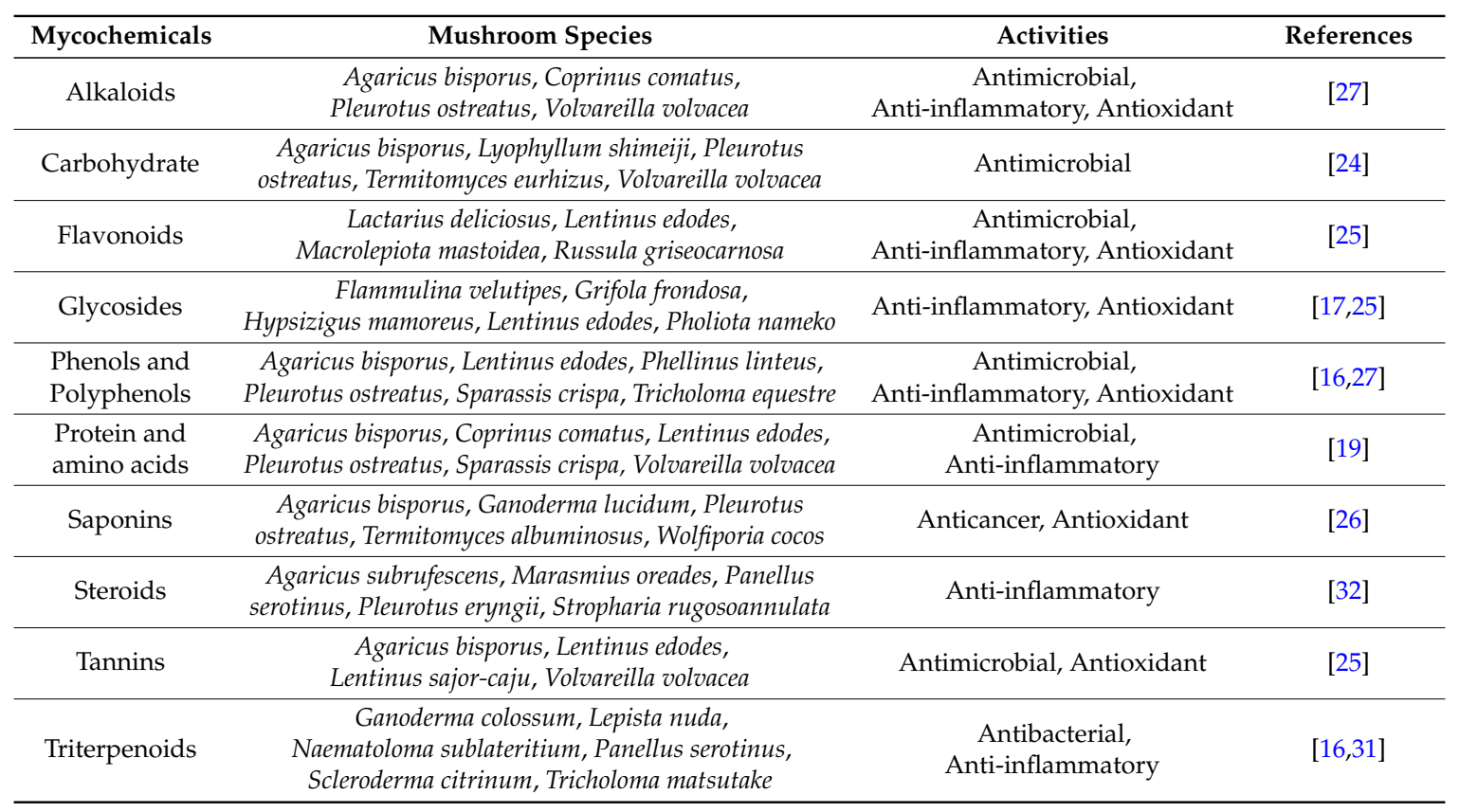

\subsection{Beneficial Components of Mushrooms}

Many studies have been done to find out more about the different components in mushrooms that are beneficial to the skin. It was found that mushrooms contain many bioactive metabolites, such as lectins, polysaccharides, phenolics and polyphenolics, terpenoids, ergosterols, and volatile organic compounds [11]. Mushroom polysaccharides, including lentian, schizophyllan, polysaccharide Kerstin (PSK), and polysaccharide peptide (PSP), are now available on the pharmaceutical market. A large amount, if not all, higher Basidiomycetes mushrooms contain biologically-active polysaccharides in fruiting bodies, cultured mycelia, and cultured broth [22,34].

Mushroom chitosan is also widely used in cosmetology as an emulgatory, gel-forming, protective, and anti-bacterial agent [33]. Chitin-glucan is a copolymer found in the cell wall of several mushrooms with good moisturizing properties, can help fight against some of the signs of skin aging, and has potential for use in skin moisturizing and anti-aging formulations [35]. Tremella extracts make an exotic addition to comprehensive skin care products which are applicable in treatment of neurodermatitis and sclerodermatitis [36]. Some mushrooms are also used in biotransformation and the products such as lactic acid and ceramides could potentially be used in cosmetics [37]. Lactic acid is an alpha hydroxy acid used in cosmetic preparations in dermatology to hydrate and smooth dry, flaking skin. Ceramides are also used in cosmetics as epidermal hydrating agents, but they are expensive due to scarcity. Some mushroom extracts are even capable of accelerating the skin turnover rate and repairing dermal molecular components that provide structure and elasticity to the skin [38].

\subsubsection{Phenolic and Polyphenolic Compounds}

Phenolic and polyphenolic compounds are aromatic hydroxylated compounds, possessing one or more aromatic rings with one or more hydroxyl groups, being commonly found in many 
mushrooms [39]. These compounds exhibit a wide range of biological effects due to free radical scavenging and antioxidant activity. Phenolic compounds can be classified as simple phenols and phenolic acids, such as gallic acid, kojic acid, benzoic acid, syringic acid, chlorogenic acid, and other associates, and polyphenols, which are further classified into many groups, such as flavonoids, tannins, stilbenes, and so on [40]. Kojic acid is commonly found in several mushrooms which is useful as a natural skin lightener and has been added to creams, lotions, and serums as a remedy for age spots and discolorations [41]. Kojic acid is assumed to help inhibit melanin production on the surface of treated skin, thereby lightening the new skin cells that form after the dead ones are exfoliated.

Flavonoids are the most common and widely distributed group of plant phenolics and have been shown to be highly effective scavengers of most types of oxidizing molecules, including singlet oxygen and various free radicals. The antioxidant activities are considered to be possibly involved in DNA damage and tumor promotion $[42,43]$. Flavonoids can be classified into flavonols, flavones, flavanols, flavanones, anthocyanins, and isoflavonoids. The health-promoting effects of flavonoids have been identified as antioxidant, anti-inflammatory, and anti-proliferative activities, inhibition of bioactivating enzymes, or induction of detoxifying enzymes [44].

\subsubsection{Terpenoids}

Terpenoids are a large and diversified group of organic compounds similar to terpenes, derived from five-carbon isoprene units. Most known terpenoids in mushrooms were found in Ganoderma spp., containing a wide range of terpenes and terpene derivatives, such as ganodermic and ganoderic acids, ganoderals, ganoderols, ganodermanontriol, lanostane, lucidone, and ganodermanondiol, which show immumomodulating and anti-infective activities $[45,46]$. Carotenoids are widely used in cosmetics, especially in sun lotions, which are organic pigments found in many mushrooms and can be split into two classes, xanthophylls and carotenes [47].

\subsubsection{Selenium}

Selenium (Se) is an ultra-trace essential element for mammals and essential in different selenoproteins and/or selenoenzymes. Agaricus bisporus and Lentinus edodes are edible mushrooms that accumulate Se in their bodies [48,49]. Selenium compounds in selenized garlic such as $\gamma$-glutamyl-Se-methylselenocysteine and Se-methylselenocysteine (MeSeCys) are potent anti-tumor agents [50]. Selenium can benefit bone health and strengthen the teeth, hair, and nails, which is widely applied in shampoo.

\subsubsection{Polysaccharides}

Most of mushroom polysaccharides are homoglycans or heteroglycans (depending on types of monosaccharide molecules in polysaccharides) and are able to combine with other proteins to make peptidoglycan or polysaccharide-protein complexes. Polysaccharides, especially $\beta-(1-3)-D-g l u c a n$, which have anti-cancer properties have been found in numerous fungi and are used in cosmetics, e.g., in Pleurotus spp. [51]. $\beta-(1-3)-D-G l u c a n$ with triple helical structure was first isolated from the fruiting body of Lentinus edodes in the late 1960s in Japan [52]. Since then schizophyllan from Schizophyllum commune, lentinan from Lentinus edodes, protein-bound PSK from Coriolus versicolor, and $\beta$-(1-6)-D-glucan from Agaricus subrufescens have been isolated by different groups [53-55]. Lentinan is an active compound incorporated in cream which can stimulate the immune system, strengthening its ability to fight infection and disease [56]. All these polysaccharides showed immune-modulation activity and some have been incorporated into cosmetics products.

\section{Cosmetics: Category and Progress}

Cosmetics can be classified into two categories of cosmeceuticals for topical application and nutricosmetics for oral one. Cosmeceuticals applies only to products applied topically, such as creams, lotions, and ointments, while nutricosmetics are known with similar perceived benefits but that are ingested orally (so-called inner beauty). There are many requirements for cosmetics products, but most 
importantly they should be safe to use, with no side effects, and have positive effects on the skin. In recent years, natural products have attracted extensive attention in cosmetics. There are numerous products from fungi that are being exploited in cosmeceuticals or nutricosmetics, and many potential products are yet to be used [14]. Shiitake mushroom, alone, has several applications in cosmetics, ranging from an exfoliant to an anti-inflammatory, encourages faster skin renewal, and increases skin elasticity as a skin brightener. Reishi mushrooms have been used in anti-aging skincare products since the 1980s, starting with Japanese brand Menard. In the early 2000s, mushrooms hit the Western market for skincare applications. Mushroom extracts, capsules, and oils are also used for topical applications as they offer their own anti-aging skin care benefits. Some of cosmetic products containing mushroom extracts or ingredients are summarized in Table 2. In the following section, we will focus on the effects of moisturizing, anti-aging, and skin whitening of mushrooms and their ingredients afterwards.

Table 2. Cosmetic products containing mushrooms and their ingredients.

\begin{tabular}{|c|c|c|}
\hline Product Name & Mushroom/Extract Included & Function \\
\hline $\begin{array}{l}\text { Aveeno Positively Ageless Daily Exfoliating } \\
\text { Cleanser, U.S. }\end{array}$ & Lentinula edodes & $\begin{array}{l}\text { Lift away dirt, oil and makeup and fight } \\
\text { signs of aging }\end{array}$ \\
\hline $\begin{array}{l}\text { One Love Organics Vitamin D Moisture } \\
\text { Mist, U.K. }\end{array}$ & Lentinula edodes & Part lightweight moisturizer and part toner \\
\hline $\begin{array}{l}\text { Osmia Organics Luz Facial Brightening } \\
\text { Serum, U.S. }\end{array}$ & Lentinula edodes extract & Skin looking bright and luminous \\
\hline CV Skinlabs Body Repair Lotion, U.S. & Ganoderma lucidum & Wound-healing and anti-inflammatory \\
\hline $\begin{array}{l}\text { Dr. Andrew Weil for Origins Mega-Mushroom } \\
\text { Skin Relief Face Mask, U.S. }\end{array}$ & Ganoderma lucidum & Anti-inflammatory properties \\
\hline $\begin{array}{l}\text { Four Sigma Foods Instant Reishi Herbal } \\
\text { Mushroom Tea, U.K. }\end{array}$ & Ganoderma lucidum & Immunity boost \\
\hline $\begin{array}{l}\text { Kat Burki Form Control Marine Collagen } \\
\text { Gel, U.K. }\end{array}$ & Ganoderma lucidum & $\begin{array}{l}\text { Boost collagen, improve elasticity and } \\
\text { provide hydration }\end{array}$ \\
\hline Menard Embellir Refresh Massage, France & Ganoderma lucidum & Skin anti-aging \\
\hline Moon Juice Spirit Dust, U.S. & Ganoderma lucidum & Immune system \\
\hline $\begin{array}{l}\text { Tela Beauty Organics Encore Styling } \\
\text { Cream, U.K. }\end{array}$ & Ganoderma lucidum & $\begin{array}{l}\text { Provide hair with sun protection and } \\
\text { prevent color fading }\end{array}$ \\
\hline $\begin{array}{l}\text { Yves Saint Laurent Temps Majeur Elixir De } \\
\text { Nuit, France }\end{array}$ & Ganoderma lucidum & Anti-aging \\
\hline Vitamega Facial Moisturizing Mask, Brazil & $\begin{array}{l}\text { Agaricus subrufescens (also } \\
\text { known as A. brasiliensis) }\end{array}$ & Renew and revitalize skin \\
\hline Kose Sekkisei Cream, Japan & Cordyceps sinensis & $\begin{array}{l}\text { Moisturizer and suppress } \\
\text { melanin production }\end{array}$ \\
\hline $\begin{array}{l}\text { Root Science RS Reborn Organic Face } \\
\text { Mask, U.S. }\end{array}$ & Inonotus obliquus & $\begin{array}{l}\text { Anti-inflammatory to help soothe } \\
\text { irritated skin }\end{array}$ \\
\hline $\begin{array}{l}\text { Alqvimia Eternal Youth Cream Facial Máxima } \\
\text { Regeneración, Spain }\end{array}$ & Schizophyllum commune & Anti-aging and lifting \\
\hline Sulwhasoo Hydroaid, Korea & Schizophyllum commune extract & $\begin{array}{l}\text { Hydrating cream promoting clear, } \\
\text { radiant skin }\end{array}$ \\
\hline $\begin{array}{l}\text { La Prairie Advanced Marine Biology Night } \\
\text { Solution, Switzerland }\end{array}$ & Tremella fuciformis & $\begin{array}{l}\text { Moisturizer which nourishes, revitalizes } \\
\text { and hydrates skin }\end{array}$ \\
\hline $\begin{array}{l}\text { BeautyDiy Aqua Circulation Hydrating } \\
\text { Gel, Taiwan }\end{array}$ & Tremella polysaccharide & Moisturizing gel \\
\hline Surkran Grape Seed Lift Eye Mask, U.S. & Tremella polysaccharide & Improve skin around eyes \\
\hline $\begin{array}{l}\text { Hankook Sansim Firming Cream (Tan Ryuk } \\
\text { SANG), Korea }\end{array}$ & $\begin{array}{l}\text { Ganoderma lucidum and } \\
\text { Pleurotus ostreatus }\end{array}$ & Make skin tight and vitalized \\
\hline La Bella Figura Gentle Enzyme Cleanser, Italia & $\begin{array}{l}\text { Ganoderma lucidum and } \\
\text { Lentinula edodes extracts }\end{array}$ & Antioxidants and vitamin D \\
\hline Pureology NanoWorks Shineluxe, France & $\begin{array}{l}\text { Ganoderma lucidum, Lentinula } \\
\text { edodes, and Mucor miehei }\end{array}$ & Anti-age and anti-fade \\
\hline $\begin{array}{l}\text { Snowberry Bright Defense Day Cream No. 1, } \\
\text { New Zealand }\end{array}$ & Mushroom extract & $\begin{array}{l}\text { Hydrate and illuminate dull skin, along } \\
\text { with anti-bacterial properties to help } \\
\text { prevent acne }\end{array}$ \\
\hline Murad Invisiblur Perfecting Shield, U.S. & Mushroom peptides & $\begin{array}{l}\text { Diminish fine lines and wrinkles by aiding } \\
\text { regulation of collagen and elastin }\end{array}$ \\
\hline
\end{tabular}




\subsection{Cosmeceuticals}

Cosmeceuticals are cosmetic-pharmaceutical hybrids intended to enhance beauty through ingredients that provide additional health-related function or benefit [57]. Topically, they are applied as cosmetics, but contain ingredients that influence the skin's biological function [58]. The lines of cosmeceutical products consist of both veterinary and human therapy. The main product lines of veterinary cosmeceuticals are shampoos and anti-ectoparasites, among which Mera-pet (Merapet Inc., Ahmedabad, India) is probably the most popular brand in Western markets. The main product lines of human cosmeceuticals are anti-aging, with a few anti-acne or moisturizing products. Common brands include Bliss (Hut.com Ltd, Cheshire, UK), La Roche (F. Hoffmann-La Roche Ltd, Basel, Switzerland), Nu-Derm (Obagi Medical Products Inc., Irvine, CA, USA), and SensiClear (Mission Scientific Skincare Inc., Gold River, CA, USA). Almost all now include products related with mushrooms and mushroom extracts [59].

\subsection{Nutricosmetics}

Nutricosmetics are nutritional supplements whose purpose is to support the function and the structure of the skin. Characterized by oral supplementation of nutrients, nutricosmetics are also known as "beauty pills", "beauty from within", and even "oral cosmetics". The major claim is the anti-aging effect, reducing wrinkles by fighting free radicals generated by solar radiation [60]. Nutricosmetics are usually based on combinations of the following ingredients: carotenoids, polyphenols, several vitamins, mushroom extracts (e.g., polyphenolic isoflavones), micronutrients, glycopolyglycans, amino acids, other mushroom-based elements, and polyunsaturated fatty acids [61]. Some nutricosmetics examples are Grifola frondosa fruit body extracts with beneficial influences on skin quality and body exterior appearance, and Sparassis crispa oral supplements with healing effects on diabetic wounds and synthesis of type I collagen and epithelization.

\section{Moisturizing Effect}

The water content of the stratum corneum and skin surface lipids are important factors in the appearance and function of skin [62]. Moisturizers decelerate the loss of skin humidity and minimize fine wrinkles. They also increase hydration of the stratum corneum and improve physical and chemical properties of skin surface, making it moist, smooth, and soft [63]. Traditional moisturizing ingredients, such as pantothenic acid, 6-palmitoyl-L-ascorbic acid and hyaluronic acid, are known as an effective moisturizing activity in cosmetic formulations.

The polysaccharide isolated from a hot water extract of a Tremella mushroom without adding a chemical reagent was found to have a novel effect of inhibiting melanin formation effects and lightening the spots on the skin when applied to the skin [64,65]. In addition, the Tremella polysaccharide showed excellent moisturizing effects. Another study revealed that cosmetics added with $0.05 \%$ Tremella polysaccharides had better moisture retention capacity than that added with $0.02 \%$ hyaluronic acid [66]. A carboxymethylated polysaccharide (CATP) derived from water-insoluble crude Tremella fuciformis polysaccharide obtained a moisture retention rate of $65.7 \%$ after $96 \mathrm{~h}$, which were slightly lower than chitosan $(70.3 \%)$. These results indicated the significant moisture retention capacity of CATP comparing to chitosan [67]. The moisture retention capacity of water extracts of Auricularia fuscosuccinea (Montagne) Farlow was found as potent as that of sodium hyaluronate, but less than that of Tremella fuciformis sporocarp extracts [68]. The mushroom powder of Fomes officinalis (also known as Laricifomes officinalis) was applied to an anhydrous cosmetic composition for reducing the shiny appearance of skin and improving the appearance of skin imperfections [69]. All of these showed potential application of mushroom polysaccharides as effective moisturizing agents in cosmetics. 


\section{Anti-Aging Effect (Lifting and Firming)}

Aging is a gradual process that results in a dysfunction and reduced reserve capacity of all body organs [63]. Anti-aging research refers exclusively to slowing, preventing, or reversing the aging process. Aging may be intrinsic or extrinsic [70]. Restated, the score of the aging process at any time depends on the outcome of dynamic interactions between biological (intrinsic), psychological (intrinsic and extrinsic), and environmental factors. The final pathway to all of the mechanisms of aging is apparently the same and involves disruption of the network of collagen and elastin [71]. Anti-aging cosmeceuticals are, therefore, designed to repair and/or maintain the body's maintenance and repair systems (MRSs) [72]. Antioxidants play a large role in the MRSs. Several types of mushrooms are used in topical creams, serums, and facial preparations as anti-aging ingredients.

\subsection{Antioxidant Activity}

There have been numerous studies of antioxidant activity of mushroom with various application in cosmetics. Lentinula edodes and Volvariella volvacea extracts demonstrate antioxidant activities and free radical scavenging abilities [73,74]. This pharmacological effect is correlated with phenolic compounds content in mushrooms as already known for grape fruits and wine [75]. Lentinula edodes is also an inducer of superoxidase dismutase (SOD) and glutathione peroxidase (GPx), two antioxidant enzymes which are known for protecting skin from oxidative damage and reversing fibrosis through reversion of myofibroblasts back to fibroblasts [76]. L-ergothioneine, a thiourea derivative of histidine which could reduce the oxidation to mitochondrial membrane, was discovered in high concentrations in Lentinus edodes, Pleurotus ostreatus, Pleurotus eryngii, Grifola frondosa, and portabellas (brown Agaricus bisporus) [77]. The antioxidant and immune activity of glucan from Phellinus ribis was evaluated in mice using lymphocyte proliferation assay [78]. The glucan isolated from an alkaline extract from a somatic hybrid mushroom of Calocybe indica var. APK2 and Pleurotus florida showed antioxidant properties with immune activation of macrophage, splenocyte, and thymocyte [79]. Therefore it is not surprising that intrinsic antioxidant properties demonstrated in vitro, with Ganoderma lucidum or Phellinus linteus can be transferred in vivo after mushroom consumption as food or nutriceutical food $[7,80]$.

\subsection{Anti-Wrinkle Activity}

Wrinkle formation is one of the primary characteristics of skin aging; the major cause of fine wrinkles is the loss of structural protein (type I collagen) in the dermal layer of skin [72]. Elastase is a metalloproteinase involved in the degradation of elastin in skin aging and the inhibition or the repair of wrinkle formation while matrix metalloproteinases (MMPs) are induced by collagen and elastin degradation. Extract of the mycelium of Tricholoma matsutake (pine mushroom) significantly decreased elastase activity in a dose-dependent manner and reduced the levels of MMPs [81]. These extracts might prove to be an effective biomaterial for anti-wrinkle treatment in cosmetics products. The methanol extract from the fruiting body of Dictyophora indusiata (veiled lady mushroom) was evaluated for its anti-cholinesterase, skin anti-wrinkle and melanogenesis inhibitory activity [82]. The collagenase and elastase inhibitory activities of the extract were comparable with the positive control epigallocatechin gallate (EGCG), which suggested a good candidate natural anti-cholinesterase and skin care agents.

The pro-inflammatory catalytic activity of cyclooxygenase-2 (COX-2) also plays a key role in the aging process. COX-2 is a rate-limiting factor in the production of prostaglandins (PGs), including prostaglandin E2 (PGE2), which causes vasodilatation and induction of other inflammatory mediators in the skin [83]. Thus, COX-2 inhibitory compounds could potentially be very useful in a variety of therapeutic and cosmetic applications. The hexane extracts of Grifola frondosa mycelia, consisting of three ergosterol compounds, were reported with COX-2 inhibitory and antioxidant activities [18]. The ethanol extract of fruiting bodies of Elaphomyces granulatus (deer truffle) was evaluated for their COX-2 inhibitory activity in mouse macrophages RAW 264.7 revealing two active compounds of 
syringaldehyde and syringic acid [84]. All of these could be incorporated as beneficial compositions against skin aging.

\section{Skin Whitening Effect}

White skin is an aspiration of every woman because it signifies wealth and beauty, especially in Asia. Melanin synthesis was the major source of skin color and played an important role in protection of UV-induced dermal irritation $[85,86]$. The biosynthetic pathway for melanin formation in various bioforms is mainly regulated by tyrosinase in two distinct oxidation reactions [87]. Basically, tyrosinase catalyses the hehydroxylation of tyrosine to dihydroxyphenylalanine (DOPA) and the oxidation of DOPA to DOPAquinone, which is further converted to eumelanin (brown-black pigment) or pheomelanin (yellow-red pigment), depending on different physiological conditions. Thus, tyrosinase inhibition is the most common approach to achieve skin whitening [88].

Many mushrooms have presented tyrosinase inhibition activity including Agaricus bisporus, Agaricus hortensis, Ganoderma spp., and Phellinus baumii. The methanol extract from fruiting bodies of Phellinus baumii showed inhibitory activities of tyrosinase and melanin synthesis by dose dependent manner in B16/F10 melanoma cells [89,90]. Flammulina velutipes extracts were also demonstrated to suppress melanin synthesis and tyrosinase activity in B16 murine melanoma cells [91]. Compared to other basidiomycetes, Ganoderma lucidum exhibited the highest inhibition against tyrosinase activity [92]. Currently many of the facial mask cosmetics in the market contain Ganoderma extracts.

\section{Hair Cosmetics}

Hair cosmetics are designed to both maintain the hygiene of the scalp and manipulate the structural properties of hair [93]. The formulations of hair cosmetics include shampoos, conditioners, serums, hair styling products (sprays, waxes, gels, and mousses), straightening products, bleaching agents, perming agents, and hair dyes [94]. Prescription medications, such as minoxidil and finasteride, are often focused on improving scalp hair density [95]. Many postmenopausal women may achieve a better cosmetic look if the medical prescription is combined with cosmetic hair care products, which may increase hair fiber diameter in a nonpermanent way.

Shampoos are formulated for cleansing the hair and scalp and have been adapted to the variations associated with hair quality, hair care habit, and specific problems, such as treatment of oily hairs, dandruff, and for androgenic alopecia [96]. Tremella mushrooms contain a hydrophilic agent-polysaccharide glucuronoxylomannan (GXM) with anti-inflammatory and wound-healing properties largely used in cosmetology [36]. A small silk film shiitake mushroom extract has been included and patented as a haircare cosmetic composition. Another composition for promoting hair growth in humans was issued with Ganoderma lucidum combined with three other plants and zinc which could stimulate hair growth in a human male by diminishing dihydrotestosterone or prostatic hyperplasia levels [97].

Like the rest of the body, healthy hair requires the delivery of vital nutrients to the hair follicles. Deficiency of these nutrients, as well as external factors like harsh chemical treatments, unhealthy lifestyle, and prolonged illness can cause hair problems. Mushrooms are a good source of vitamin D, antioxidants and minerals like iron, selenium, and copper, which are all useful in both promoting healthy and strong hair and preventing hair loss and dandruff. The inclusion of mushrooms and/or extracts into haircare cosmetics is of great potential in the cosmetic industry.

\section{Conclusions}

As a traditional source of natural bioactive compounds, mushrooms are now being exploited for potential ingredients in the cosmetics industry. Several mushrooms and their extracts are either presently used or patented to be used as cosmetics products for their antioxidant, anti-aging, anti-wrinkle, skin whitening, and moisturizing effects. 
As aforementioned, the mushroom species presently identified and utilized only account for a small percentage of total amount, and more species will be discovered, verified, and cultivated. All of these indicate further exploitation and boosting of the development of the cosmetic industry. With interdisciplinary studies combined with genomics, proteomics, metabolomics, and systems pharmacology, the molecular mechanisms of medicinal effects of mushrooms (so-called the research area of molecular cosmetology) will be revealed and more mushrooms can find their way into cosmetics with multiple approaches.

Acknowledgments: This study was supported with the support of Forest Science \& Technology Projects (Project No. S121314L080100, 2015) by Korea Forest Service. Yuanzheng Wu wishes to express his gratitude to the China Scholarship Council (CSC) and the Young Scientist Exchange Program between the Republic of Korea and the People's Republic of China.

Author Contributions: Yuanzheng $\mathrm{Wu}$ and Moon-Hee Choi wrote the paper; Jishun Li, Hetong Yang and Hyun-Jae Shin revised the paper.

Conflicts of Interest: The authors declare no conflict of interest.

\section{Abbreviations}

The following abbreviations are used in this manuscript:

$\begin{array}{ll}\text { CATP } & \text { Carboxymethylated Polysaccharide } \\ \text { COX-2 } & \text { Cyclooxygenase-2 } \\ \text { DOPA } & \text { Dihydroxyphenylalanine } \\ \text { EGCG } & \text { Epigallocatechin Gallate } \\ \text { GPx } & \text { Glutathione Peroxidase } \\ \text { GXM } & \text { Glucuronoxylomannan } \\ \text { MMPs } & \text { Matrix Metalloproteinases } \\ \text { MRSs } & \text { Maintenance and Repair Systems } \\ \text { PGE2 } & \text { Prostaglandin E2 } \\ \text { PGs } & \text { Prostaglandins } \\ \text { PSK } & \text { Polysaccharide Krestin } \\ \text { PSP } & \text { Polysaccharide Peptide } \\ \text { Se } & \text { Selenium } \\ \text { SOD } & \text { Superoxidase Dismutase }\end{array}$

\section{References}

1. Cheung, P.C. Mushrooms as Functional Foods; John Wiley \& Sons: Hoboken, NJ, USA, 2008; pp. 1-34.

2. Miles, P.G.; Chang, S.T. Mushrooms: Cultivation, Nutritional Value, Medicinal Effect, and Environmental Impact, 2nd ed.; CRC Press: Boca Raton, FL, USA, 2004; pp. 1-26.

3. Wasser, S.P. Current findings, future trends, and unsolved problems in studies of medicinal mushrooms. Appl. Microbiol. Biotechnol. 2011, 89, 1323-1332. [CrossRef] [PubMed]

4. Mueller, G.M.; Schmit, J.P. Fungal biodiversity: What do we know? What can we predict? Biodivers. Conserv. 2007, 16, 1-5. [CrossRef]

5. Kirk, P.M.; Cannon, P.F.; Minter, D.W.; Stalpers, J.A. Ainsworth and Bisby's Dictionary of the Fungi, 10th ed.; Centre for Agriculture and Biosciences International: Wallingford, UK, 2008.

6. Poucheret, P.; Fons, F.; Rapior, S. Biological and pharmacological activity of higher fungi: 20-Year retrospective analysis. Cryptogam. Mycol. 2006, 27, 311-333.

7. Ahmad, M.F.; Ahmad, F.A.; Azad, Z.; Ahmad, A.; Alam, M.I.; Ansari, J.A.; Panda, B.P. Edible mushrooms as health promoting agent. Adv. Sci. Focus 2013, 1, 189-196. [CrossRef]

8. Bashir, A.; Vaida, N.; Dar, M.A. Medicinal importance of mushrooms-A review. Int. J. Adv. Res. 2014, 2, 1-4.

9. Chang, S.T.; Wasser, S.P. The role of culinary-medicinal mushrooms on human welfare with a pyramid model for human health. Int. J. Med. Mushrooms 2012, 14, 95-134. [CrossRef] [PubMed]

10. El Enshasy, H.A.; Hatti-Kaul, R. Mushroom immunomodulators: Unique molecules with unlimited applications. Trends Biotechnol. 2013, 31, 668-677. [CrossRef] [PubMed]

11. Kalač, P. A review of chemical composition and nutritional value of wild-growing and cultivated mushrooms. J. Sci. Food Agric. 2013, 93, 209-218. [CrossRef] [PubMed] 
12. Millikan, L.E. Cosmetology, cosmetics, cosmeceuticals: Definitions and regulations. Clin. Dermatol. 2001, 19, 371-374. [CrossRef]

13. Antignac, E.; Nohynek, G.J.; Re, T.; Clouzeau, J.; Toutain, H. Safety of botanical ingredients in personal care products/cosmetics. Food Chem. Toxicol. 2011, 49, 324-341. [CrossRef] [PubMed]

14. Hyde, K.D.; Bahkali, A.H.; Moslem, M.A. Fungi-An unusual source for cosmetics. Fungal Divers. 2010, 43, 1-9. [CrossRef]

15. Camassola, M. Mushrooms-The incredible factory for enzymes and metabolites productions. Ferment. Technol. 2013, 2. [CrossRef]

16. Badalyan, S.M. The main groups of therapeutic compounds of medicinal mushrooms. Med. Mycol. 2001, 3, 16-23.

17. Liu, J. Biologically active substances from mushrooms in Yunnan, China. Heterocycles 2002, 57, $157-167$.

18. Zhang, Y.; Mills, G.L.; Nair, M.G. Cyclooxygenase inhibitory and antioxidant compounds from the mycelia of the edible mushroom Grifola frondosa. J. Agric. Food Chem. 2002, 50, 7581-7585. [CrossRef] [PubMed]

19. Choi, M.H.; Han, H.K.; Lee, Y.J.; Jo, H.G.; Shin, H.J. In vitro anti-cancer activity of hydrophobic fractions of Sparassis latifolia extract using AGS, A529, and HepG2 cell lines. J. Mushroom 2014, 12, 304-310. [CrossRef]

20. Van Griensven, L.J. Culinary-medicinal mushrooms: Must action be taken? Int. J. Med. Mushrooms 2009, 11, 281-286. [CrossRef]

21. Wani, B.A.; Bodha, R.H.; Wani, A.H. Nutritional and medicinal importance of mushrooms. J. Med. Plants Res. 2010, 4, 2598-2604.

22. Wasser, S.P. Medicinal mushroom science: History, current status, future trends, and unsolved problems. Int. J. Med. Mushrooms 2010, 12, 1-16. [CrossRef]

23. Chandrasekaran, G.; Oh, D.S.; Shin, H.J. Versatile applications of the culinary-medicinal mushroom Mycoleptodonoides aitchisonii (Berk.) Maas G. (Higher Basidiomycetes): A review. Int. J. Med. Mushrooms 2012, 14, 395-401. [CrossRef] [PubMed]

24. De Silva, D.D.; Rapior, S.; Hyde, K.D.; Bahkali, A.H. Medicinal mushrooms in prevention and control of diabetes mellitus. Fungal Divers. 2012, 56, 1-29. [CrossRef]

25. Mortimer, P.E.; Karunarathna, S.C.; Li, Q.; Gui, H.; Yang, X.; Yang, X.; Hyde, K.D. Prized edible Asian mushrooms: Ecology, conservation and sustainability. Fungal Divers. 2012, 56, 31-47. [CrossRef]

26. Lee, B.; Park, J.; Park, J.; Shin, H.J.; Kwon, S.; Yeom, M.; Sur, B.; Kim, S.; Kim, M.; Lee, H.; et al. Cordyceps militaris improves neurite outgrowth in Neuro2A cells and reverses memory impairment in rats. Food Sci. Biotechnol. 2011, 20, 1599-1608. [CrossRef]

27. Mattila, P.; Könkö, K.; Eurola, M.; Pihlava, J.M.; Astola, J.; Vahteristo, L.; Hietaniemi, V.; Kumpulainen, J.; Valtonen, M.; Piironen, V. Contents of vitamins, mineral elements, and some phenolic compounds in cultivated mushrooms. J. Agric. Food Chem. 2001, 49, 2343-2348. [CrossRef] [PubMed]

28. Bernaś, E.; Jaworska, G.; Lisiewska, Z. Edible mushrooms as a source of valuable nutritive constituents. Acta Sci. Pol. Technol. Aliment. 2006, 5, 5-20.

29. Choi, Y.; Lee, S.M.; Chun, J.; Lee, H.B.; Lee, J. Influence of heat treatment on the antioxidant activities and polyphenolic compounds of Shiitake (Lentinus edodes) mushroom. Food Chem. 2006, 99, 381-387. [CrossRef]

30. Meng, T.X.; Furuta, S.; Fukamizu, S.; Yamamoto, R.; Ishikawa, H.; Arung, E.T.; Kondo, R. Evaluation of biological activities of extracts from the fruiting body of Pleurotus citrinopileatus for skin cosmetics. J. Wood Sci. 2011, 57, 452-458. [CrossRef]

31. Deepalakshmi, K.; Mirunalini, S. Therapeutic properties and current medical usage of medicinal mushroom: Ganoderma lucidum. Int. J. Pharm. Sci. Res. 2011, 2, 1922-1929.

32. Chiu, S.W.; Law, S.C.; Ching, M.L.; Cheung, K.W.; Chen, M.J. Themes for mushroom exploitation in the 21st century: Sustainability, waste management, and conservation. J. Gen. Appl. Microbiol. 2000, 46, 269-282. [CrossRef] [PubMed]

33. Badalyan, S.M. Potential of mushroom bioactive molecules to develop healthcare biotech products. In Proceedings of the 8th International Conference on Mushroom Biology and Mushroom Products, New Delhi, India, 19-22 November 2014.

34. Smith, J.E.; Rowan, N.J.; Sullivan, R. Medicinal mushrooms: A rapidly developing area of biotechnology for cancer therapy and other bioactivities. Biotechnol. Lett. 2002, 24, 1839-1845. [CrossRef]

35. Gautier, S.; Xhauflaire-Uhoda, E.; Gonry, P.; Piérard, G.E. Chitinglucan, a natural cell scaffold for skin moisturization and rejuvenation. Int. J. Cosmet. Sci. 2008, 30, 459-469. [CrossRef] [PubMed] 
36. De Baets, S.; Vandamme, E.J. Extracellular Tremella polysaccharides: Structure, properties and applications. Biotech. Lett. 2001, 23, 1361-1366. [CrossRef]

37. Gao, J.M.; Zhang, A.L.; Chen, H.; Liu, J.K. Molecular species of ceramides from the ascomycete truffle Tuber indicum. Chem. Phys. Lipids 2004, 131, 205-213. [CrossRef] [PubMed]

38. Bowe, W.P. Cosmetic benefits of natural ingredients: Mushrooms, feverfew, tea, and wheat complex. J. Drugs Dermatol. 2013, 12, s133-s136. [PubMed]

39. Ferreira, I.C.; Barros, L.; Abreu, R. Antioxidants in wild mushrooms. Curr. Med. Chem. 2009, 16, $1543-1560$. [CrossRef] [PubMed]

40. Kim, M.Y.; Seguin, P.; Ahn, J.K.; Kim, J.J.; Chun, S.C.; Kim, E.H.; Seo, S.H.; Kang, E.Y.; Kim, S.L.; Park, Y.J.; et al. Phenolic compound concentration and antioxidant activities of edible and medicinal mushrooms from Korea. J. Agric. Food Chem. 2008, 56, 7265-7270. [CrossRef] [PubMed]

41. Bentley, R. From miso, sake and shoyu to cosmetics: A century of science for kojic acid. Nat. Prod. Rep. 2006, 23, 1046-1062. [CrossRef] [PubMed]

42. Wright, J.S.; Johnson, E.R.; DiLabio, G.A. Predicting the activity of phenolic antioxidants: Theoretical method, analysis of substituent effects, and application to major families of antioxidants. J. Am. Chem. Soc. 2001, 123, 1173-1183. [CrossRef] [PubMed]

43. Liu, R.H. Potential synergy of phytochemicals in cancer prevention: Mechanism of action. J. Nutr. 2004, 134, 3479S-3485S. [PubMed]

44. Le Marchand, L. Cancer preventive effects of flavonoids-A review. Biomed. Pharmacother. 2002, 56, $296-301$. [CrossRef]

45. Gao, Y.; Zhou, S.; Jiang, W.; Huang, M.; Dai, X. Effects of ganopoly (a Ganoderma lucidum polysaccharide extract) on the immune functions in advanced-stage cancer patients. Immunol. Investig. 2003, 32, 201-215. [CrossRef]

46. Jeong, Y.T.; Yang, B.K.; Jeong, S.C.; Kim, S.M.; Song, C.H. Ganoderma applanatum: A promising mushroom for antitumor and immunomodulating activity. Phytother. Res. 2008, 22, 614-619. [CrossRef] [PubMed]

47. Jin, J.M.; Lee, J.; Lee, Y.W. Characterization of carotenoid biosynthetic genes in the ascomycete Gibberella zeae. FEMS Microbiol. Lett. 2010, 302, 197-202. [CrossRef] [PubMed]

48. Racz, L.; Bumbalova, A.; Harangozo, M.; Tölgyessy, J.; Tomeček, O. Determination of cesium and selenium in cultivated mushrooms using radionuclide X-ray fluorescence technique. J. Radioanal. Nucl. Chem. 2000, 245, 611-614. [CrossRef]

49. Ogra, Y.; Ishiwata, K.; Encinar, J.R.; Łobiński, R.; Suzuki, K.T. Speciation of selenium in selenium-enriched shiitake mushroom, Lentinula edodes. Anal. Bioanal. Chem. 2004, 379, 861-866. [CrossRef] [PubMed]

50. McSheehy, S.; Yang, W.; Pannier, F.; Szpunar, J.; Łobiński, R.; Auger, J.; Potin-Gautier, M. Speciation analysis of selenium in garlic by two-dimensional high-performance liquid chromatography with parallel inductively coupled plasma mass spectrometric and electrospray tandem mass spectrometric detection. Anal. Chim. Acta 2000, 421, 147-153. [CrossRef]

51. Synytsya, A.; Míčková, K.; Synytsya, A.; Jablonský, I.; Spěváček, J.; Erban, V.; Kováříkovád, E.; Čopíková, J. Glucans from fruit bodies of cultivated mushrooms Pleurotus ostreatus and Pleurotus eryngii: Structure and potential prebiotic activity. Carbohydr. Polym. 2009, 76, 548-556. [CrossRef]

52. Ikekawa, T. Beneficial effects of edible and medicinal mushrooms on health care. Int. J. Med. Mushrooms 2001, 3, 79-86.

53. Hobbs, C. The chemistry, nutritional value, immunopharmacology, and safety of the traditional food of medicinal split-gill fugus Schizophyllum commune Fr.: Fr. (Schizophyllaceae). A literature review. Int. J. Med. Mushrooms 2005, 7, 127-140. [CrossRef]

54. Angeli, J.P.; Ribeiro, L.R.; Bellini, M.F.; Mantovani, M.S. $\beta$-Glucan extracted from the medicinal mushroom Agaricus blazei prevents the genotoxic effects of benzo[a]pyrene in the human hepatoma cell line HepG2. Arch. Toxicol. 2009, 83, 81-86. [CrossRef] [PubMed]

55. Yao, N.; White, P.J.; Alavi, S. Impact of $\beta$-glucan and other oat flour components on physico-chemical and sensory properties of extruded oat cereals. Int. J. Food Sci. Technol. 2011, 46, 651-660. [CrossRef]

56. Bisen, P.S.; Baghel, R.K.; Sanodiya, B.S.; Thakur, G.S.; Prasad, G.B. Lentinus edodes: A macrofungus with pharmacological activities. Curr. Med. Chem. 2010, 17, 2419-2430. [CrossRef] [PubMed]

57. Oricha, B.S. Cosmeceuticals: A review. Afr. J. Pharm. Pharmacol. 2010, 4, 127-129. 
58. Anuradha, S.N.; Vilashene, G.; Lalithambigai, J.; Arunkumar, S. "Cosmeceuticals": An opinion in the direction of pharmaceuticals. Asian J. Pharm. Clin. Res. 2015, 8, 64-69.

59. Choi, C.M.; Berson, D.S. Cosmeceuticals. Semin. Cutan. Med. Surg. 2006, 25, 163-168. [CrossRef] [PubMed]

60. Anunciato, T.P.; da Rocha Filho, P.A. Carotenoids and polyphenols in nutricosmetics, nutraceuticals, and cosmeceuticals. J. Cosmet. Dermatol. 2012, 11, 51-54. [CrossRef] [PubMed]

61. Barel, A.O.; Paye, M.; Maibach, H.I. 55 Use of food supplements as nutricosmetics in health and fitness. In Handbook of Cosmetic Science and Technology, 4th ed.; CRC Press: Boca Raton, FL, USA, 2014; pp. 583-596.

62. Sator, P.G.; Schmidt, J.B.; Hönigsmann, H. Comparison of epidermal hydration and skin surface lipids in healthy individuals and in patients with atopic dermatitis. J. Am. Acad. Dermatol. 2003, 48, 352-358. [CrossRef] [PubMed]

63. Baumann, L. Skin ageing and its treatment. J. Pathol. 2007, 211, 241-251. [CrossRef] [PubMed]

64. Yang, S.H.; Liu, H.I.; Tsai, S.J. Edible Tremella Polysaccharide for Skin Care. U.S. Patent US20060222608, 5 October 2006.

65. Zhang, K.; Meng, X.Y.; Sun, Y.; Guo, P.Y. Preparation of Tremella, Speranskiae tuberculatae and Eriocaulon buergerianum extracts and their performance in cosmetics. Deterg. Cosmet. 2013, 36, $28-32$.

66. Liu, H.; He, L. Comparison of the moisture retention capacity of Tremella polysaccharides and hyaluronic acid. J. Anhui Agric. Sci. 2012, 40, 13093-13094.

67. Wang, X.; Zhang, Z.; Zhao, M. Carboxymethylation of polysaccharides from Tremella fuciformis for antioxidant and moisture-preserving activities. Int. J. Biol. Macromol. 2015, 72, 526-530. [CrossRef] [PubMed]

68. Liao, W.C.; Hsueh, C.Y.; Chan, C.F. Antioxidative activity, moisture retention, film formation, and viscosity stability of Auricularia fuscosuccinea, white strain water extract. Biosci. Biotechnol. Biochem. 2014, 78, 1029-1036. [CrossRef] [PubMed]

69. Sandewicz, I.M.; Julio, G.R.; Zhu, V.X. Anhydrous Cosmetic Compositions Containing Mushroom Extract. U.S. Patent US6645502, 11 November 2003.

70. Kosmadaki, M.G.; Gilchrest, B.A. The role of telomeres in skin aging/photoaging. Micron 2004, 35, 155-159. [CrossRef] [PubMed]

71. Khare, N.; Khare, P.; Yadav, G. Recent advances in anti-aging-A review. Glob. J. Pharm. 2015, 9, $267-271$.

72. Lupo, M.P.; Cole, A.L. Cosmeceutical peptides. Dermatol. Ther. 2007, 20, 343-349. [CrossRef] [PubMed]

73. Cheung, L.M.; Cheung, P.C. Mushroom extracts with antioxidant activity against lipid peroxidation. Food Chem. 2005, 89, 403-409. [CrossRef]

74. Puttaraju, N.G.; Venkateshaiah, S.U.; Dharmesh, S.M.; Urs, S.M.; Somasundaram, R. Antioxidant activity of indigenous edible mushrooms. J. Agric. Food Chem. 2006, 54, 9764-9772. [CrossRef] [PubMed]

75. Landrault, N.; Poucheret, P.; Ravel, P.; Gasc, F.; Cros, G.; Teissedre, P.L. Antioxidant capacities and phenolics levels of French wines from different varieties and vintages. J. Agric. Food Chem. 2001, 49, 3341-3348. [CrossRef] [PubMed]

76. Cheung, L.M.; Cheung, P.C.; Ooi, V.E. Antioxidant activity and total phenolics of edible mushroom extracts. Food Chem. 2003, 81, 249-255. [CrossRef]

77. Dubost, N.J.; Beelman, R.B.; Peterson, D.; Royse, D.J. Identification and quantification of ergothioneine in cultivated mushrooms by liquid chromatography-mass spectroscopy. Int. J. Med. Mushrooms 2006, 8, $215-222$. [CrossRef]

78. Yuan, C.; Huang, X.; Cheng, L.; Bu, Y.; Liu, G.; Yi, F.; Yang, Z.; Song, F. Evaluation of antioxidant and immune activity of Phellinus ribis glucan in mice. Food Chem. 2009, 115, 581-584. [CrossRef]

79. Maity, K.; Kar, E.; Maity, S.; Gantait, S.K.; Das, D.; Maiti, S.; Maiti, T.K.; Sikdar, S.R.; Islam, S.S. Structural characterization and study of immunoenhancing and antioxidant property of a novel polysaccharide isolated from the aqueous extract of a somatic hybrid mushroom of Pleurotus florida and Calocybe indica variety APK2. Int. J. Biol. Macromol. 2011, 48, 304-310. [CrossRef] [PubMed]

80. Sun, J.; He, H.; Xie, B.J. Novel antioxidant peptides from fermented mushroom Ganoderma lucidum. J. Agric. Food Chem. 2004, 52, 6646-6652. [CrossRef] [PubMed]

81. Kim, S.Y.; Go, K.C.; Song, Y.S.; Jeong, Y.S.; Kim, E.J.; Kim, B.J. Extract of the mycelium of T. matsutake inhibits elastase activity and TPA-induced MMP-1 expression in human fibroblasts. Int. J. Mol. Med. 2014, 34, 1613-1621. [CrossRef] [PubMed] 
82. Nguyen, T.K.; Shin, D.B.; Lee, K.R.; Shin, P.G.; Cheong, J.C.; Yoo, Y.B.; Lee, M.W.; Jin, G.H.; Kim, H.Y.; Im, K.H.; et al. Antioxidant and anti-inflammatory activities of fruiting bodies of Dyctiophora Indusiata. J. Mushroom 2013, 11, 269-277. [CrossRef]

83. Cao, Y.; Prescott, S.M. Many actions of cyclooxygenase-2 in cellular dynamics and in cancer. J. Cell. Physiol. 2002, 190, 279-286. [CrossRef] [PubMed]

84. Stanikunaite, R.; Khan, S.I.; Trappe, J.M.; Ross, S.A. Cyclooxygenase-2 inhibitory and antioxidant compounds from the truffle Elaphomyces granulatus. Phytother. Res. 2009, 23, 575-578. [CrossRef] [PubMed]

85. Lin, J.; Chiang, H.; Lin, Y.; Wen, K. Natural products with skin-whitening effects. J. Food Drug Anal. 2008, 16, 1-10.

86. Gupta, S.K.; Gautam, A.; Kumar, S. Natural skin whitening agents: A current status. Adv. Biol. Res. 2014, 8, 257-259.

87. Parvez, S.; Kang, M.; Chung, H.S.; Bae, H. Naturally occurring tyrosinase inhibitors: Mechanism and applications in skin health, cosmetics and agriculture industries. Phytother. Res. 2007, 21, 805-816. [CrossRef] [PubMed]

88. Chang, T.S. An updated review of tyrosinase inhibitors. Int. J. Mol. Sci. 2009, 10, 2440-2475. [CrossRef] [PubMed]

89. Kim, D.; Park, J.; Kim, J.; Han, C.; Yoon, J.; Kim, N.; Seo, J.; Lee, C. Flavonoids as mushroom tyrosinase inhibitors: A fluorescence quenching study. J. Agric. Food Chem. 2006, 54, 935-941. [CrossRef] [PubMed]

90. Lee, J.S.; Shin, D.B.; Lee, S.M.; Kim, S.H.; Lee, T.S.; Jung, D.C. Melanogenesis inhibitory and antioxidant activities of Phellinus baumii methanol extract. Korean J. Mycol. 2013, 41, 104-111. [CrossRef]

91. Nagasaka, R.; Ishikawa, Y.; Inada, T.; Ohshima, T. Depigmenting effect of winter medicinal mushroom Flammulna velutipes (higher Basidiomycetes) on melanoma cells. Int. J. Med. Mushrooms 2015, 17, 511-520. [CrossRef] [PubMed]

92. Chien, C.C.; Tsai, M.L.; Chen, C.C.; Chang, S.J.; Tseng, C.H. Effects on tyrosinase activity by the extracts of Ganoderma lucidum and related mushrooms. Mycopathologia 2008, 166, 117-120. [CrossRef] [PubMed]

93. Draelos, Z.D. Hair cosmetics. In Hair Growth and Disorders; Springer Science \& Business Media: Berlin, Germany; Heidelberg, Germany, 2008; pp. 499-513.

94. Madnani, N.; Khan, K. Hair cosmetics. Indian J. Dermatol. Venereol. Leprol. 2013, 79, 654-667. [CrossRef] [PubMed]

95. Dias, M.F. Hair cosmetics: An overview. Int. J. Trichol. 2015, 7, 2-15. [CrossRef] [PubMed]

96. Nazir, H.; Wang, L.; Lian, G.; Zhu, S.; Zhang, Y.; Liu, Y.; Ma, G. Multilayered silicone oil droplets of narrow size distribution: preparation and improved deposition on hair. Colloids Surf. B Biointerfaces 2012, 100, 42-49. [CrossRef] [PubMed]

97. Meehan, K. Composition to Promote Hair Growth in Humans. U.S. Patent US9144542, 29 September 2015. 